Татьяна МиннияхметовА (Pécs)

\title{
Рефрлексивность символов в ритуальное время (на примере святых мест закамских удмуртов)
}

Предложенная тема привлекала мое внимание лишь в последнее время и я предлагаю обратить внимание на некоторые ее аспекты, поделиться моими наблюдениями и замечаниями, потому что при подготовке данной статьи обнаружился ряд непонятных мне и проблематичных вопросов. В действительности выражение «в обрядовое/ритуальное время», указанное в заглавии статьи, не совсем точное или правильное, т.к. символы, в рассматриваемом случае, религиозные символы, «не допускают или не признают» различия во времени, эти символы неизменны как во времени (имеется в виду понятие о времени ритуальном и неритуальном, а не историческом), так и в пространстве. Данное выражение включено в заглавие потому, что все приведенные и анализируемые ниже примерыслучаи происходили в обрядовое время и мне пришлось сталкиваться с ними, участвуя на обрядах. На обрядах религиозные символы выражают себя ярче и используются с специальной целью, соответствующей данной обрядовой ситуации.

В последние десятилетия в гуманитарной науке изменился объект исследования. Если в прошлом наиболее интересующим направлением были статичная схема иной, т.е. чужой культуры, ее частное проявление и смысл «для нас», то теперь им становится жизнь и «внутренний» смысл этой культуры, ее движение. «При этом фокус исследований смещается с явлений культуры, взятых в статике, на их функционирование; предметом изучения становятся не столько культурные символы, сколько правила, способы и цели их использования носителями культуры в определенных ситуациях их жизни. Иными словами, в центре внимания исследователей оказывается не то, как «устроена» иная культура, а то, как она «устраивается», создается; не значения, но движения смысла (Христофорова 1998: 3). И для исследователя особо важно стремиться показать, как носители культуры сами ее «понимают, растолковывают и смыслят» (Тэрнер 1983: 112). Следуя традиционным направлениям этнографической науки, я коснусь и ее новых теоретических разработок.

Многие аспекты верований не «показывают себя» открыто, особенно сложно их уловить и раскрыть постороннему. К одному из подобных явлений относится понятие рефлексивности мышления. В данном случае 
предлагается рассмотреть идеи рефлексивности, выраженные посредством символов, используемых на обрядах. Причем в качестве символов представлены здесь как материальные вещи, так и нематериальные явления.

Материал собирался мной среди закамских удмуртов и все приведенные ниже примеры взяты из их ритуальной жизни. Рассмотрим обстановку последних десятилетий, наблюдавшуюся в этом регионе. Закамские удмурты - небольшая диаспора, расселенная в центральной части западного Приуралья (северо-западных районах Башкирии и Куединском районе Пермской области), в левобережье реки Камы. По отношению к материнскому этносу, т.е. удмуртам Удмуртии, они проживают на другой стороне Камы, поэтому в науке они получили такое название - закамские. Их общее число по итогам переписи 2002 г. (ВПН 2002) состаляет 48897 человек (из них 22625 проживает в Башкирии, 26272 - в Пермской области). Большинство закамских удмуртов проживает в сельской местности (всего в 73 населенных пунктах). В настоящее время в рассматриваемом регионе в соседстве с удмуртами проживают разные народы, отличающиеся как по языкам, так и по конфессиям: тюркоязычные башкиры и татары - мусульмане, русские - православные, финно-угры удмурты, как и здешние марийцы, придерживаются своих традиционных верований. Для их верований характерна вера человека в существование сверхъестественных сил и существ, управляющих процессами и явлениями материального и нематериального мира. Основные их формы проявляются в анимизме, культе предков, тотемизме, фетишизме, магии (колдовство, ведовство), различных аграрных и промысловых культах. Природные стихии, строго почитаемые до настоящего времени: вода, огонь, земля, воздух. Религиозные представления выражаются ярче всего в обрядовой жизни, что развито и действительно и у рассматриваемых удмуртов. Именно обрядовая культура способствует сохранению их верований, т.к. религия закамских удмуртов представляет собой устную традицию, подразделяемую по родовым и территориальным признакам, хотя различия между этими подразделениями не значительны.

Как указывалось выше, религия народа ярче всего проявляется в обрядах и в связанных с представлениями объектах, предметах. Не исключение и жизнь закамских удмуртов.

Рассматриваемые удмурты имеют участки земель, на территории которых они справляют свои религиозные обряды и молятся своим богам и духам. Каждый населенный пункт обладает несколькими участками 
святых и молельных мест на лугу и в поле, лесу и на поляне, у водоемов и в овраге. Кроме того, в каждой усадьбе на юго-восточной стороне имеется святое место. В жилом доме таким местом является стол - kuriśkon žök, красный угол - törošor (как правило, оба располагаются на юго-восточной части помещения) и другая от входной двери половина дома, подразделенная матицей - mumykor śör. Каждый из указанных участков считается запрещенным для посторонних пространством. Переступить границу между святым и обычным участками разрешено лишь в случае, когда там проводится какой-либо обряд. Пребывание на святых местах в необрядовое время влечет за собой порицание.

Молельные места обычно располагаются у водоемов или источников вод. Каждое подобное место имеет название, связанное с справляемым там обрядом. Наиболее важное моление - Великое или Общественное моление - Bydzym vöś/Mör vöś. Их справляют в дни летнего и зимнего солнцестояний. В некоторых деревнях для Великих молений выделены по нескольку участков. Другое, не менее значительное моление - Lud или Keremet. Данное молельное место расположено в отдельном месте и на этом обряде могут принимать участие только представители мужского пола, независимо от их возраста.

Кроме указанных, имеются еще специальные места для проводов льда весной, молений за спор и удачу при выполнении посевных работ и их завершения, в честь рождения земли и взошедшей зелени и т.п.

Рассмотрим некоторые символы, присутствующие в обрядовое время, прежде всего обращая внимание на то, как люди их используют и с какой целью. Одна из функций этих символов - их способность отражать желания и стремления людей, т.е. рефлексивность. Рассмотрим понятие рефлексивности символов, согласно представлению и растолкованию носителей культуры, которые мне удалось выяснить и обнаружить на обрядах во время полевых работ, оказавшись на некоторых из них случайно, на других - по специальному приглашению. Следует сказать, к тому времени я не имела конкретного к этой теме интереса и не преследовала особой цели, подчиненной теме рефлексивности.

Традиционно большинство святых или молельных мест имеют форму круга и его южная часть воспринимается как пространство богов и духов, которым посвящается или в честь которых совершается тот или иной обряд. Прибыв на место моления (речь идет о летнем молении), прежде всего скашивают на нем траву, после чего границы святилища четко выделяются. В южной его части жрецы и их помощники сооружают 
«полевые ворота» - inös: в направлении с востока на запад втыкают в землю два березовых кола 1,5-2 м высотой и отдаленных друг от друга на два-три метра и сверху соединяют их, складывая длинную жердь. После этого развешивают на ней ритуальные полотенца. Севернее от этой линии, т.е. «небесных ворот», устанавливают котел для приготовления еды, кострище, «конструируют стол» на земле, раскладывая березовые ветки, на стволе дерева устанавливают место для подношения пожертвований богам. Восточная часть святого места - женская, западная - мужская. На всех участках молельного места, за исключением пространства за «небесными воротами», могут находиться только жрецы и их помощники.

\section{Примеры}

Здесь я приведу несколько примеров, которые не являются обычными и общеизвестными (или для меня были неизвестны до этого времени).

В июне 1995 года в дер. Вылись Асау было совершено Великое моление - Mör vöś на прекрасной цветущей и благоухающей полуовражной поляне, с юга которой протекала речка. К обеду к этому месту начал стекаться народ для участия на молении. Одна пожилая женщина, вступая в сакральное пространство, произнесла как для себя: Kyše šuldyr karill'am, ulon no syše med luoz inde - «Как красиво убрали (имеется в виду молельное место), пусть и жизнь такой же будет».

Другой случай связан с моментом, когда все приступили есть обрядовую кашу и мясо. Я находилась рядом с пожилой женщиной, которая принимала участие в приготовлении еды. Когда мы приступили к еде, ее внучка, примерно 8 лет, подошла к нам. Каша в тарелке с маслом в середине была очень горячая, и эта маленькая девочка, возможно, могла не знать всех правил в подобной ситуации, поэтому эта женщина, ее бабушка, мягко сказала: Suratek gyne baśty, nyly, durtiz, medaz söriśky «Возьми (кашу) не мешая, доченька, с краешка, чтоб не испортить (формы каши)».

В тот раз на этом молении пожертвовали утку и овцу. Как правило, после поедания мяса необходимо принести оставшиеся кости к костру чтоб сжечь их: отдельно от каждого пожертвованного животного. Некоторые участники, подходя с костями к костру, смотрели на жреца с вопросом «куда сложить какие кости?» (без слов, лишь взглядом). Жрец ответил им словами: Pall'an palaz - čöžleśze, bur palaz - yžleśze - «Слева кости от утки, справа - от овцы». Здесь не имеется в виду понятие «слева - справа» как две оппозиции, а с левой, восточной, стороны находилось 
кострище, на котором было приготовлено мясо утки, а справа, с запада, было другое кострище, где соответственно было приготовлено мясо овцы.

Следующий пример обнаружился также случайно, когда я проводила полевые исследования в дер. Кӧйгурт в июле 2000 года. Прибыла я туда несколькими днями позже после проведения обряда Kepeмem. Я остановилась в семье дальних родственников по материнской линии и они разрешили посмотреть обрядовое место. Мы сходили туда с детьми из той семьи: дочерью, 14 лет, и сыном, 15 лет. По дороге к месту Керемет они рассказывали мне об этом обряде, как его совершают обычно и что было в последний раз. На удивление, они оба были компетентны во всех вопросах и деталях, что меня поразило. На месте проведения обряда они показали и уточняли многие моменты их рассказа, услышанного мной по дороге. На двух березах были развешаны платки и полотенца - пожертвования от каждой семьи, принимавшей участие на обряде. Время от времени сопровождавшие меня дети поговаривали между собой и о других вещах. Но в один момент сестра спросила своего брата: Todiśkod-a, kudze źalykez $V$-y šuysa ponizy? - «Знаешь ли ты, который платок повесили для В. (имя специально не указано) ?» Я не поняла, о чем идет речь, кто такой В. и который из пожертвованных платков «особый». Позже я все же выяснила этот вопрос и оказалось, что прошлой весной В. был призван в армию и его семья (родители, собратья) посредством этой жертвы пожелала ему отслужить и здоровым-невредимым вернуться домой.

Каждая деревня имеет также святое место иного характера, это кладбища. Традиционно кладбища посещаются людьми ежегодно два раза - в дни весенних и осенних общественных поминок. Кроме того, обязательны поминальные визиты после смерти человека через 3, 7, 40 дней и через год. Известно, что традиции и обычаи, связанные с усопшими, наиболее консервативные. Подобными они являются и у удмуртов Закамья.

В один из обычных весенних поминальных дней в мае 2002 года (дер. Байшады) побывали мы с моей мамой на нашем кладбище. По дороге на кладбище мы встретили многих односельчан, «навестивших умерших» и возвращающихся оттуда домой. Обычно в такой ситуации не принято приветствовать встречных людей: ни возвращающимся с кладбища, ни направляющимся туда. Один из приближающихся к нам мужчин сказал нам: Salam verazy pereśjos - «Старики (т.е. умершие) передали привет». Другой посетитель добавил: Siźyloź en vetle ni, šuizy, mi čogasa bertiśkom inde. - «До осени не приходите больше (на кладбище), сказали (умершие), мы возвращаемся уже закрывая (входные ворота кладбища)». 
Рассмотрим понятие рефлексивности символов, исходя из приведенных примеров и укажем, как носители культуры видят и разъясняют значение символов, способных отражать их желания и стремления.

Согласно российским исследователям, о рефлексивности архаического мышления следует говорить в случае, когда не только «любая, в том числе и не знаковая, реальность воспринимается как реплика, несущая ожидания своего отправителя» (Новик 1994: 157), но и «свои собственные поступки человек рассматривает прежде всего с точки зрения того, какой смысл они имеют для партнера по взаимодействию, как они будут им интерпретированы, и, соответственно, какой последует на них ответ» (Христофорова 1998: 22).

В представленных выше примерах приводились различные случаи, которые, как указывалось выше, рассматриваются как символы. Эти символы выражены в словах, поступках людей, в конкретных вещах. В действительности, эти вещи также являются и результатами человеческой деятельности. Но все данные символы нацелены поддержать мир и его естественное продолжение, позитивно развиваясь. Данный аспект выделен здесь, и их значения не неопределенные и смутные, а ясные.

В первом примере жрецы и их помощники готовили святое место для проведения моления, и это ясно (для носителей культуры), что они убрали его с тем же смыслом: если все будет выполнено согласно правилам, то и ожидания будут положительными. Выражение восхищения, высказанное пожилой женшиной, когда она переступала границу святилища, заключает в себе как минимум два значения: первое, оно подтверждает действие жрецов, которое соответствует данному случаю (т.е. место моления подготовлено для проведения обряда правильно); второе, оно показывает ее личное желание, на что она рассчитывала и что ожидала здесь увидеть («пусть жизнь будет такой!»)

Второй пример, связанный с моментом поедания ритуальной каши, показывает, что форма каши в тарелке с маслом в середине - это нечто специально сотворенное совершенство, что не должно быть нарушено. В противоположность этому - весь период приготовления ритуальной каши, когда ее необходимо беспрестанно мешать по солнцу вплоть до ее полной готовности.

В третьем примере говорилось о костях пожертвованных животных утки и овцы - как было разъяснено, ничего не должно быть смешано, потому что созданный порядок следует поддержать, а не нарушать (см. предыдущий пример о совершенстве формы каши - имеет то же зна- 
чение). Кроме этого, во время молений запрещено ломать или раздроблять кости пожертвованных животных.

Примеры с платками и полотенцами, развешанными на деревьях с пожеланиями вернуться со службы живым и невредимым. Как правило, если кто-либо совершает подобный обряд-пожелание, посвященное специальной цели, то он/она представляет мысленно все, как оно могло бы быть и могло сложиться в идеале. Здесь члены семьи мысленно «описывают» весь предстоящий путь призывника с момента покидания дома и возвращения домой после службы в армии. Данный пожертвованный платок заключает в себя жизнь и благополучие молодого человека в определеннный период его жизни. Когда он, отслужив в армии, вернется, данный платок с дерева будет снят и сожжен на очередном молении деревни.

Последние примеры о случаях, произошедших по дороге на кладбище. Выражение «Старики (т.е. умершие) передали привет» имеет несколько значений, демонстрирующих положительные пожелания людей, т.е. односельчан. Если «старики», т.е. умершие предки, передают привет, то это значит, что они «чувствуют» себя хорошо, они довольны; если они довольны и согласны с нами, т.е. живыми и здравствующими, то они желают нам добра и блага; если тем самым они поддерживают нас, то все сложится хорошо и у нас на этом свете.

Следующее выражение «До осени не приходите больше (на кладбище), сказали (умершие), мы возвращаемся уже закрывая (входные ворота кладбища)» означает, что люди высказывают желание, чтоб до следующего поминального периода никто не умер и чтоб люди пришли сюда только поминать усопших, а не с другой целью (т.е. не с целью похоронить кого-либо).

Уходя с кладбища, мы с мамой также «закрыли» кладбищенские ворота: гвоздем (специально предназначенным для этого, который обычно лежит на столбе у ворот) трижды провели черту от столба до столба. Этим действием мы тоже подтвердили пожелания наших односельчан и свои личные - чтоб никто не умер до следующих поминок.

Естественно, все рассмотренные примеры представляют символы с различными значениями. Но в данном случае указывалось, как люди вкладывают значения в эти символы, тем самым отражая в них свои ожидания с надеждой, что эти символы отразят их пожелания. Хорошо известное представление, что люди своим поведением не могут спровоцировать нежелаемые реакции, и подобное действие может стать 
причиной множества отрицательных последствий как для того, кто их совершил, также для общества в целом. Я разделяю это мнение не полностью, а предполагаю, что человек ожидает не награду или наказание, а предписанное для всех поведение, направленное на его ожидания.

\section{Заключение}

Понятие и представление о рефлексивности присутствуют в сознании людей постоянно, они регулируют их действия и поведение в целом. Это как строгий закон, общее для всех правило, смысл жизни, что поддерживают модель повседневной жизни. Рефлексивность обнаруживает и прагматический аспект мышления. Хотя нет необходимости, что кто-то должен являться прямым «слушателем», но мысленно оно прямо адресовано кому-то или ко всем в целом. В каждом случае присутствует «отправляющий» и «принимающий», которые связаны особой коммуникативной связью. Поэтому символизм устроен строго не только семантически, но и прагматически. И он показывает последовательность и постоянство/стойкость. Но в то же время рефлексивность мышления держит человека в постоянном стрессе, т.е. рефлексивность мышления требует от каждого действий и поведения согласно строгому обдуманному намерению.

Конечно, эти примеры были «обнаружены» случайно, т.к. в традиционном обществе нет причин и необходимости разъяснять и растолковывать происходящее, людьми управляет всеобщее знание, и это совершенно ясно и очевидно. И в ритуальное время было бы невежливо нарушать естественный ход событий своим любопытством и вопросами. Обычно подобное вмешательство исследователя-полевика в обрядовый процесс оказывает свое влияние и на ответы людей тоже. Таким образом, рассмотренные примеры-символы не являются неизменными и постоянными, они живут, развиваясь и изменяясь, чтоб соответствовать ситуации и ответить назначению. И для того, чтобы «эта информация «проснулась», символ должен быть помещен в какой-либо современный контекст, что неизбежно трансформирует его значение» (Лотман 2000: 618). В таком случае символ имеет действующую и влиятельную силу.

Приведенные выше примеры ясно показывают, как определенный способ мышления может стать путем создания и обустройства мира вокруг, и тем самым - мир в целом. И данный аспект показывает также, что в течение своей жизни человек выступает как активная сила, не только как зависящая, а как способная повлиять на его окружающий мир, обсто- 
ятельства, свою судьбу. Но следует иметь в виду, что рефлексивность мышления имеет множество «функций» и может быть представлен и растолкован с различных точек зрения в одно и то же время. Необходимо иметь как можно больше примеров и случаев, чтоб найти разъяснения очевидным и скрытым значениям.

Для общества же важно, что подобные случаи призывают к ментальному процессу участников коммуникации в различных ситуациях: психологическому, социо-культурному.

\section{Ссылки}

ВПН $2002=$ Всероссийская перепись населения 2002 года. http://www.perepis2002.ru.

Лотман, Ю. М. 2000: Семиосфера. Санкт-Петербург.

Новик, Е. С. 1994: Архаические верования в свете межличностной коммуникации. - Историко-этнографические исследования по фольклору: Сборник статей памяти С. А. Токарева. Москва.

Тэрнер, В. 1983: Символ и ритуал. Москва.

Христофорова, О. Б. 1998: Логика толкований. Фольклор и моделирование поведения в архаических культурах. Чтения по истории и теории культуры. Вып. 25. Москва.

Татьяна Миннияхметова <minnijah@ hotmail.com>

Dept. of Ethnography and Cultural Anthropology

University of Pécs

HU-7624 Pécs, Rókus 2 